\title{
Economic Returns from Burning Tobosagrass in the Texas Rolling Plains
}

\section{D.E. ETHRIDGE, R.G. SUDDERTH, AND H.A. WRIGHT}

\begin{abstract}
Based on 7 prescribed burning trials on tobosagrass (Hilaria mutica) in the Rolling Plains of Texas from 1968 to 1976, burned tobosagrass ranges yielded an additional present value of $\$ 36.16 / \mathrm{ha}$ (\$14.64/ac) over 5 years with calf prices at $\$ 1.62 / \mathrm{kg}(\$ .731 \mathrm{lb})$. Additional costs are \$10-12.50/ha (\$4-5/ac). These results are based on average precipitation on ranges which had prior chemical treatment on mesquite. The prescribed burns were conducted
\end{abstract} according to recommended practices.

Tobosagrass (Hilaria mutica (Torr.) Benth.) is a grass which builds up large quantities of litter (Wright 1969). This litter makes tobosagrass less palatable to cattle and decreases both plant and animal production as litter accumulates. Burning removes excess litter and increases the grass palatability and yield for several years. Although cattle will use tobosagrass after a burn (Heirman and Wright 1973), the investment decisions are affected by soil moisture and economic considerations, including livestock prices and interest rates on borrowed capital.

Prior research on prescribed burning of tobosagrass has been on the physical relationships involved. Wright (1972) studied fire as a management tool in mesquite-tobosagrass communities; 1 location was in the High Plains and 6 were in the Rolling Plains of Texas. His results showed that burned plots reached equilibrium with unburned plots in about 5 years, and reburns could be conducted every 5 to 8 years without forage loss, depending on the site. Tobosagrass is most heavily used in the first and second year after burning. Also, burning improved tobosagrass productivity, controlled broomweed, reduced cactus, removed dead mesquite wood, and killed some honey mesquitc ( $P$. glandulosa Torr. var. glandulosa).

Heirman and Wright (1973) measured the effects of burning on the composition and production of a High Plains grass community and on cattle use of tobosagrass. Tobosagrass production increased threefold the first year after the burn. They concluded that in mixed stands of tobosagrass and buffalograss (Buchloe dactyloides (Nutt.) Engelm.), grazing pressure was absorbed primarily by tobosagrass during spring and again in late summer-early fall.

On 5 burned and unburned locations in the Rolling Plains, Wright (1969) concluded that fire could control mesquite without adversely affecting tobosagrass production. Yield of tobosagrass was higher on all burned plots compared to the unburned plots. Also, late spring and early summer rainfall most influenced tobosagrass production. Bunting et al. (1978), working on the southwestern edge of the Rolling Plains, found that (1) elimination of excess litter was a major reason for increased tobosagrass production, (2) tobosagrass and other herbs reached equilibrium with control plots by the end of the fifth year after burning, and (3) growing season rainfall following the burn was very important.

Workman (1976) described an economic analysis of prescribed burning which consisted of comparing treatment cost with discounted net annual returns. The identified factors which affected the economic feasibility of a prescribed burn were: (1) herbage increase, (2) percentage of this which could be harvested, (3) value of each added unit of forage, (4) life of the treatment, (5) treatment

\footnotetext{
The authors are associate professor and research assistant. Agricultural Economics Department, and chairman and Horn professor, Range and Wildlife Management Department, Texas Tech University, Lubbock 79409.

This article is Texas Tech University College of Agricultural Sciences Publication No. T-1-221.

The authors wish to acknowledge the contribution of R.D. Pettit, B.E. Dahl, T.J. Neal, B.G. Freeman, the editors, and two anonymous reviewers in the preparation of this paper.

Manuscript accepted January 21, 1985.
}

cost, and (6) the interest rate on borrowed capital. He illustrated the procedure with an example on sagebrush burning.

The objective here is to develop a procedure and evaluate the economic feasibility of burning tobosagrass on the Texas Rolling Plains under varying economic circumstances. This will allow decision makers to consider several variables affecting future returns.

\section{Analytical Framework}

Prescribed burning of tobosagrass constitutes a capital investment because the major expense occurs at one time and the effects of the burn extend into the future. Since the effects are expected to last several years, there are two risks: (1) physical, such as weather variation, and (2) economic uncertainty, a rising mostly from variations in livestock prices. Effectiveness of prescribed burning, in conjunction with certain economic variables, largely determines the feasibility of burning.

The basis for this analysis is a herbage yield response function relating marginal (additional) grass production (yield) resulting from a prescribed burn (MGP) to time (t) and other variables, $X \dot{i}$ :

$$
\mathrm{MGP}=\mathrm{f}\left(\mathrm{t}, \mathrm{X}_{\mathrm{i}}\right)
$$

MGP is expected to decline over time because of litter buildup after the burn. Additional grass production is converted to additional (marginal) livestock production (MLP), or:

$$
M L P=k(M G P)=h\left(t, X_{i}\right)
$$

where MLP is additional livestock production per unit of land associated with prescribed burning and $\mathrm{k}$ is units of livestock per unit of grass (a conversion factor for converting grass to meat). Equations (1) and (2) are biological relationships. Equation (2) is transformed into the value of additional grass production (VMGP) by multiplying by the unit value of livestock produced net of added unit costs of production, ' PL:

VMGP $=(M L P)(P L)=j\left(t, X_{i}\right)$

Range managers cannot affect the market value of the livestock. VMGP is the added revenue from prescribing burning, and there is a VMGP each year during which the burn has an impact on grass and livestock production. If all costs of burning occur at the time of the burn, the stream of additional returns must be discounted in order to place them on an equivalent basis with the cost (Whitson and Scifres 1980). Thus,

$$
P V M P=\sum_{t}\left[V M G P_{t} /(1+r)^{t}\right]
$$

where PVMP is present value of added revenue from prescribed burning, $V M G P$ is added revenue from the burn in year $t$, and $r$ is the discount rate, i.e., the price of capital used for the burn. The longer the life of the burn $(t)$ and the lower interest rate $(r)$, the greater the present value of the revenue generated from prescribed burning.

If PVMP is greater than or equal to the cost of burning, the burn is economically feasible. To estimate costs and returns, several things must be known: (1) the nature of the MGP and/or the MLP relationship, (2) the value of livestock, and (3) the cost of prescribed burning. Value of livestock is difficult to forecast, especially

\footnotetext{
'The value of additional grass production as used here is a net value added in terms of livestock production, i.e.. it is net of additional costs associated with producing more livestock. However, it is a gross value in terms of prescribed burning; it shows the total value of burning which is directly comparable to the cost of burning.
} 
over a long period. The grass or livestock production response relationship requires identification of factors which affect productivity of the prescribed burn and quantitative estimation of impacts of those factors.

\section{Methods and Procedures}

Data on grass yield after prescribed burning were obtained from studies by Neuenschwander (1976) and Wright $(1969,1972)$. These studies had observations for burns up to 5 years old. All locations were in the Rolling Plains of Texas, and all burns were conducted on range which had prior chemical mesquite control treatment.

Variables having effects on grass yield after a burn in equation (1) included: (a) time, (b) rainfall during the growing season, (c) rainfall during the period preceding the growing season, (d) slope of the terrain, and (e) site where the burn was conducted. The relationship between MGP and each of the independent variables except time was hypothesized to be linear and the relationship with time nonlinear (semi-log) form. The mathematical model formulated was:

$$
\begin{aligned}
& \mathrm{MGP}=\mathrm{B} 0+\mathrm{B} 1 \mathrm{R} 1+\mathrm{B} 2 \mathrm{R} 2+\mathrm{B} 3 \ln \mathrm{t}+\mathrm{B} 4 \mathrm{D} 1+\mathrm{B} 5 \mathrm{D} 2+\mathrm{B} 6 \mathrm{D} 3+ \\
& \mathrm{B} 7 \mathrm{D} 4+\mathrm{B} 8 \mathrm{D} 5
\end{aligned}
$$

where MGP = added grass production from burning ( $\mathrm{kg} / \mathrm{ha})$,

RI = rainfall during the July-Feb. period prior to the growing season $(\mathrm{cm})$,

R2 = rainfall during the Mar.-June growing season (cm),

In $t$ natural logarithm of year following treatment $(1=$ year of treatment),

$\mathrm{Dl}=$ site dummy variable; $\mathrm{Dl}=$ if site is Post, Texas, $\mathrm{O}$ otherwise,

D2 = site dummy variable; $D 2=1$ if site is Guthrie, Texas, $O$ otherwise,

D3 = site dummy variable; D3 = 1 if site is Quanah, Texas, $O$ otherwise,

If D1, D2, and D3 are all 0, Site is Colorado City, Texas.)

D4 = slope dummy variable; D4 = 1 if site is lowland, O otherwise, and D5 $=$ slope dummy variable; $D 5=1$ if site is upland, $O$ otherwise.

(If D4 and D5 are both 0, slope is midslope.)

The additional grass yield per year was calculated as the burned plot yield less its respective control plot yield. Data on rainfall were obtained from Climatological Data, Texas (U.S. Department of Commerce 1970). Ordinary least squares was used to estimate parameters of equation (5).

It was assumed that the livestock enterprise would be a cow-calf operation in which an animal unit (AU) would consist of $454 \mathrm{~kg}$ $(1,000 \mathrm{lb}) \mathrm{cow}$, one $181 \mathrm{~kg}(400 \mathrm{lb})$ calf, $5 \%$ of a $725 \mathrm{~kg}(1600 \mathrm{lb})$ bull, and $14 \%$ of a $295 \mathrm{~kg}(650 \mathrm{lb})$ replacement heifer (Kennedy 1970). A calving rate of $90 \%$ and marketing of calves at $181 \mathrm{~kg}$ was assumed. Thus, under these conditions, one AU produces $138 \mathrm{~kg}$ $(304 \mathrm{lb})$ of marketable calf $(.76 \times 181 \mathrm{~kg}=138 \mathrm{~kg} ; .76=.90$ calving rate minus .14 heifer replacement). The additional cull cow production from heifer replacement was accounted for with the production costs. The MGP relationship was converted to MI.P as follows. It was estimated that for the Rolling Plains areas in the study, an additional total production of $6,530 \mathrm{~kg}(14,400 \mathrm{lb})$ of tobosagrass was required to support $l$ added animal unit (AU) the first year after the burn. The following years after the burn it takes more tobosagrass to support an added $\mathrm{AU}$, because tobosagrass quality deteriorates after the burn and the forage becomes coarser through time. It was further estimated that $9,800 \mathrm{~kg}(21,600 \mathrm{lb})$ of tobosagrass was required to support an added $\mathrm{AU}$ the fifth year after a burn and in subsequent years.

If the additional grass produced can be utilized, the number of kilograms of grass required to support an animal unit for years 1 through 5 is found by $5715.3+816.5 \mathrm{t}$. Therefore, the conversion factor for converting $\mathrm{kg}$ of grass to $\mathrm{kg}$ of marketable calf becomes: $k=138 /(5715.3+816.5 t)$

The value of the calves was determined in terms of net value rather than gross value. If more animal units are placed on the land, there are added costs associated with grazing those livestock. The value of livestock marketed, PL, was calculated as:

$$
P L=P C-V P C
$$

where PC is market price of $181 \mathrm{~kg}$ calves in $\$ / \mathrm{kg}$ and $V P C$ is variable production costs for $181 \mathrm{~kg}$ calves in $\$ / \mathrm{kg}$. Variable costs consisted of those items shown in Table 1 minus the value of cull

\section{Table 1. Estimated costs associated with adding cow-calf units, Texas} Rolling Plains.

\begin{tabular}{lr}
\hline \hline Operating Costs & \\
Cottonseed cake & $\$ 9.00$ \\
Hay & 8.00 \\
Vet. medicine & 4.50 \\
Salt \& minerals & 2.10 \\
Miscellaneous & 3.00 \\
Marketing & 5.00 \\
Fence repair & 2.70 \\
Water facilities repair & 1.30 \\
Barn repair & 1.55 \\
Equipment fuel \& lub. & 2.68 \\
Equipment repair & .74 \\
Total added operating costs & $\$ 40.57$ \\
Interest on operating capital (10\%) & 4.06 \\
Depreciation, taxes, insurance on livestock & 14.34 \\
Interest on livestock investment & \\
Investment: Cow $\quad \$ 475.00$ & \\
Heifer $\quad 58.00$ & \\
Bull $\quad$ 43.67 & $\$ 576.67 \times 10 \%$ \\
Total added cost per cow-calf unit & $\$ 116.64$ \\
Cost/kg of marketed calf (116.64/138) & .8458 \\
\hline
\end{tabular}

Source: Texas Agricultural Extension Service, 1983 enterprise budget B-1241 (L6) for Texas Rolling Plains 11 region.

cows; land costs and overhead costs were excluded. The value of cull cows was determined using a price relationship between cull cow and calf prices: price of cull cows $=.1162+.4774$ (price of calves) where both prices are in $\$ / \mathrm{kg}$. This regression estimate $\left(R^{2}=\right.$ $.96 ; F=180.9$, significant at the .0001 level) was derived from 10 years of price data from the San Angelo market. Weight of cull cow used was $408 \mathrm{~kg}$ (900 lb).

\section{Results and Interpretation}

Estimation of equation (5) yielded the following relationship2: MGP $=-356.31-557.69 \ln t+73.53$ R2 $-976.06 \mathrm{D} 3$

$\begin{array}{ccc}(0.0006) & (0.0001) & (0.0795) \\ \text { The } 2 \text { slope dummy variables, D4 and D5, were insignificant as }\end{array}$ were D1 and D2, site dummy variables for Post and Guthrie, respectively. The site variable for Quanah, D3, was significant at the .08 level. The preseason rainfall variable, $R 1$, was not significant for the data used in this study. Both growing season rainfall and year were highly significant explanatory variables.

${ }^{2}$ Numbers in parentheses below the estimated regression parameters represent the probability of a greater $t$-value for the parameter (the significance level). $F=16.80$ (significant at the .0001 level), $R^{2}=.60$, and $n=38$.

Table 2. Descriptive statistics for variables in the MPG relationship.

\begin{tabular}{lcc}
\hline \hline Variable & Mean & $\begin{array}{c}\text { Standard } \\
\text { Deviation }\end{array}$ \\
\hline MGP (added grass produced) & 509.69 & 779.88 \\
ln t (logarithm of year) & 0.69 & 0.59 \\
R2 (growing season rainfall-cm) & 17.39 & 6.26 \\
D3 (site dummy variable for Quanah) & 0.03 & 0.16 \\
\hline
\end{tabular}


Table 3. Calculation of value of added grass production.

\begin{tabular}{|c|c|c|c|c|c|}
\hline Year & Added grass prod. ${ }^{1}$ & Conversion factor & Added beef prod. & $\begin{array}{c}\text { Value of } \\
\text { grass prod. }\end{array}$ & $\begin{array}{l}\text { Discounted value of } \\
\text { added prod., }\end{array}$ \\
\hline & $\mathrm{kg} / \mathrm{ha}$ & & $\mathrm{kg} / \mathrm{ha}$ & $\$ /$ ha & \$/ha \\
\hline 1 & 922.38 & .0211 & 19.46 & 22.18 & 20.16 \\
\hline 2 & 535.82 & .0188 & 10.07 & 11.48 & 9.49 \\
\hline 3 & 309.70 & .0169 & 5.23 & 5.96 & 4.48 \\
\hline 4 & 149.26 & 0153 & 2.28 & 2.60 & 1.78 \\
\hline \multirow[t]{2}{*}{5} & 24.81 & .0141 & 0.35 & 0.40 & 0.25 \\
\hline & 1941.97 & & 37.39 & 42.62 & 36.16 \\
\hline
\end{tabular}

'Conditions: Growing season rainfall of $17.39 \mathrm{~cm}(6.85 \mathrm{in})$ and D3 set equal to 0.

${ }^{2}$ Conversion factor of equation (6) is used.

${ }^{3}$ Assumes variable calf production cost of $\$ .8458 / \mathrm{kg}(\$ .38 / \mathrm{lb})$, and calf market price of $\$ 1.62 / \mathrm{kg}(\$ .73 / \mathrm{lb})$

${ }^{1} 10 \%$ Discount rate.

If the cost of burning is $\$ 12.50$ / ha ( $\$ 5 / \mathrm{ac})$, the internal rate of return is $129 \%$

To facilitate interpretation, the R2 and D3 variables in equation (8) were assigned fixed values to produce a grass yield function with added grass yield as a function of time. If D3 is set at 0 and the mean value for growing season rainfall (Table 2 ) is substituted into equation (8),

$$
\text { MGP }=922.38-557.69 \ln \mathrm{t}
$$

This relationship indicated that with normal rainfall conditions prescribed burning would produce $922 \mathrm{~kg} / \mathrm{ha}(820 \mathrm{lb} / \mathrm{ac})$ more grass the first year after the burn, $536 \mathrm{~kg} / \mathrm{ha}(477 \mathrm{lb} / \mathrm{ac})$ the second year after the burn, $310 \mathrm{~kg}$ the third year, $149 \mathrm{~kg}$ the fourth year, and $25 \mathrm{~kg}$ the fifth year (Table 3). After ycar 5, the effects of the burn are negligible. In practice, implementation of the system might involve rotational burning with say, 5 tracts and 1 tract burned each year. This would allow stability in livestock numbers rather than annual adjustment of stocking rates.

To convert the added grass yield to added beef production, the appropriate conversion factor was obtained by using equation (6). To convert to dollar values, the estimated added cost of producing the marketable calf of $\$ .8458$ less the cull calf value was used. The price of beef is subject to variation-from numerous sources, but for purposes of this analysis, the price quotations for the San Angelo market for medium frame \#1 feeders, $136-181 \mathrm{~kg}(300-400 \mathrm{lb})$ and 181-227 kg (400-500 lb) reported on 12 June 1982 were used (Texas Department of Agriculture 1982). Based on those prices, a calf price of $\$ 1.62 / \mathrm{kg}(\$ .73 / \mathrm{lb})$ was assumed. This calf price was adjusted for added production costs (\$116.64 variable production cost $/ \mathrm{AU} \div 138 \mathrm{~kg}$ calf $/ \mathrm{AU}=\$ .8458 / \mathrm{kg}$ ) and the value of cull cows [cull cow price $=\$ .1162+.4774(\$ 1.62)=\$ .8896 / \mathrm{kg} / \$ .8896(408 \mathrm{~kg}$ cow $/ \mathrm{AU}) .14 \div 138 \mathrm{~kg}$ calf $/ \mathrm{AU}=\$ .3682 / \mathrm{kg}]$. Thus, $\mathrm{PL}=\$ 1.62-$ $[\$ .8458-.3682]=\$ 1.14$, or an additional $\mathrm{kg}$ of marketable beef produces $\$ 1.14 / \mathrm{kg}(\$ .52 / \mathrm{lb})$ income above added costs.

If average rainfall conditions hold for sites other than Quanah (Table 2) and the above production cost and market price conditions hold, the present value of prescribed burning is shown in Table 3. A discount rate of $10 \%$ was assumed over the 5-year life of the burn. Under these conditions, the burn would produce $\$ 36.16 /$ ha $(\$ 14.64 / \mathrm{ac})$ additional income over the life of the burn. If burning cost is less than $\$ 36.16 /$ ha, investment in the burn is economically feasible. Current contract costs for burning mesquite-tobosagrass ranges are $\$ 10.00$ to $\$ 12.50 /$ ha $(\$ 4-5 / a c)$. Under these conditions the total cost of burning is recovered in the first year following the burn.

If any of the above conditions change, the economic feasibility may change. Returns from the Quanah site were lower than the other sites because grass response on that site was lower. If all conditions are the same as shown except there is a permanently lower growing season rainfall, then one could expect a lower return from prescribed burning. It is important that burning be avoided during drought years, because yields will be below those on unburned areas.
As with changes in physical conditions, changes in economic conditions likewise affect the economic feasibility. Economic factors which affect beef prices, costs of producing beef, and interest rates may have a substantial effect on the returns from and feasibility of prescribed burning. Magnitudes of these effects are shown in Table 4. The value of prescribed burning in the Texas Rolling Plains increases as beef prices increase and decreases as interest rates increase.

\section{Table 4. Present value of prescribed tobosagrass burning ( $\$ / h a)$ at differ- ent calf prices and discount rates.}

\begin{tabular}{lcc}
\hline Calf Price & \multicolumn{2}{c}{ Discount rate } \\
\cline { 2 - 3 }$(\$ / \mathrm{kg})$ & $10 \%$ & $15 \%$ \\
\hline 1.43 & 29.05 & 26.98 \\
1.54 & 33.23 & 30.86 \\
1.65 & 37.42 & 34.75 \\
1.76 & 41.60 & 38.63 \\
1.87 & 45.78 & 42.51 \\
\hline
\end{tabular}

\section{Conclusions}

The economic feasibility of prescribed burning of tobosagrass in the Rolling Plains of Texas depends on many variables; some are environmental, some are economic, and some may be influenced or manipulated by managers. The main environmental variable which affects added grass and beef production, and therefore economic feasibility associated with prescribed burning, is growing season rainfall. An additional consideration is that in a year when a prescribed burn is done and growing season rainfall is less than 5 inches during the first year there will be a decrease in production instead of an increase. This type of situation can be avoided by burning in late March when a better assessment of adequate soil moisture can be made (Wright 1969).

Among the economic variables which affect economic feasibility are livestock prices, costs of production, and interest rates. While an individual ranch manager is quite limited on the degree to which he may influence these variables, some impact on them through livestock production management, financial management, and marketing strategies may occur. This analysis shows the relative magnitudes of effects from the various factors on the cconomic returns from prescribed burning of tobosagrass. Based on 7 burns conducted and followed from 1968 to 1976, burned tobosagrass ranges were estimated to yield an additional \$36/ ha over a 5-year time span. To determine economic feasibility, the discounted added returns from burning must be compared to the added costs of burning. Economic feasibility may, therefore, vary with time, among ranches, and among pastures within ranches. The added forage production relationship estimated in this study is believed to be generally reliable for the Rolling Plains region. The 
appropriate values of the variables within the relationship, the appropriate factors to convert to marketable product, and the appropriate values for the economic variables will vary from one situation to another. The analytical framework, along with the MGP relationships, should be applicable to individual decision situations.

\section{Literature Cited}

Bunting, S.C., L.F. Neuenschwander, and H.A. Wright. 1978. The effect of firc on tobosagrass-mesquite community in the Rolling Plains of Texas. The Southwestern Naturalist. 23:315-338.

Heirman, A.L. and H.A. Wright. 1973. Fire in medium fuels of West Texas. J. Range Manage. 26:331-335.

Kennedy, R.P. 1970. Texas brush problems and rangeland productivity: an economic evaluation of the Rolling Plains land area. Ph.D. Diss.. Dep. Agr. Econ. and Rur. Soc.. Texas A\&M Univ.

Neuenschwander, L.F. 1976. The effect of fire in a sprayed tobosagrassmesquite community on stamford clay soils. Ph.D. Diss.. Texas Tech. Univ.
Texas Agricultural Extension Service. 1983. Texas enterprise budgets, Texas Rolling Plains II region: projected for 1982. B01241 (L6).

Texas Department of Agriculture. 1982. Texas livestock market news, published weekly.

U.S. Dep. of Commerce. 1970. Climatological data; Texas. Envir. Sci. Serv. Adm. Annual Summaries.

Whitson, R.E., and C.J. Scifres. 1980. Economic comparisons of alternatives for improving honey mesquite-infested rangeland. Tex. Agr. Exp. Sta. Bull. B-1307.

Workman, J.P. 1976. Economic Evaluation of prescribed burning projects. F.E. Busby and E. Storey, eds. Use of prescribed burning in western woodland and range ecosystems-a symposium. Utah Agr. Exp. Sta. Symposium Proceedings Series.

Wright, H.A. 1969. Effect of spring burning on tobosagrass. J. Range Manage. 22:425-427.

Wright, H.A. 1972. Fire as a tool to manage tobosagrasslands. Pamphlet reprinted from Annual Tall Timbers Fire Ecology Conference Proceedings, June 8-9. 